\section{United opposition to three-tier science in UK higher education}

\section{London}

Proposais to create a three-tier system of science research and teaching within British higher education have brought almost universal condemnation from the scientific community, with representative bodies united in their opposition.

Last July, in response to a request from the goverment, the Advisory Board for the Research Councils (ABRC), whose job is to advise the Secretary of State for Education and Science on his responsibilities for civil science, produced A Strategy for the Science Base, advocating far-reaching changes in the organization, management and support of scientific research in higher education and the research councils (see Nature 328, 280; 1987).

The most controversial of the proposals were that institutions be categorized into three types, with some being recognized as primarily teaching institutions, with no advanced research facilities; that funds be transferred from the University Grants Committee to the research councils to contribute towards the costs of research overheads; and that a series of interdisciplinary university research centres be established, linked with academic institutions not in the 'teaching category'. The government invited comments on the proposals from 'interested bodies'.

The concept of institutions devoted solely to teaching has provoked by far the most vehement opposition. The Royal Society says that despite ABRC's contention that a three-tier system could be sufficiently flexible to allow institutions to change their status, a formal definition of institutions would be final.

The Committee of Vice-Chancellors and Principals (CVCP) agrees that "no university should be restricted to a teaching role alone". The Association of University Teachers (AUT) describes the proposal as "absurd" and says that the proposed categorization is "incompatible with the objectives of university education".

While there is a broad consensus that greater concentration of research is needed, there is disagreement about the best means of achieving it. The CVCP welcomes the concept of interdisciplinary research centres as having "potentially important parts to play in the concentration process", but is concerned to know details of how the centres would be managed and funded. The Royal Society recommends that no more than 10 per cent of research council funds is channelled through any such centres. The AUT is suspicious of the proposals, particularly on the question of the management of the centres, fearing that they "may obtain autonomy, not subject to the shared academic objectives for the institution set up by its senate, and in the longer term may set themselves on the road to hiving-off into autonomous private institutions".

The AUT would prefer to see 'interdisciplinary research groups' develop through collaborative short-term project grants, leading to longer-term programme grants over a period of, say, five years "rather than being arbitrarily planted".

A joint statement from a group of scientific societies and institutions rejects the concept of interdiscplinary research centres. "This degree of selectivity has often failed in the past and there are few reasons for believing that it would be more successful in the future." The British Association for the Advancement of Science welcomes the concept of such centres as places to encourage voluntary cooperation between scientists within single institutions or between institutions.

\section{Washington}

LAST week's successful launch, after two failures, of a Titan rocket from Vandenberg Air Force Base in California does not amount to a resumption of the US space programme, but coming after an equally

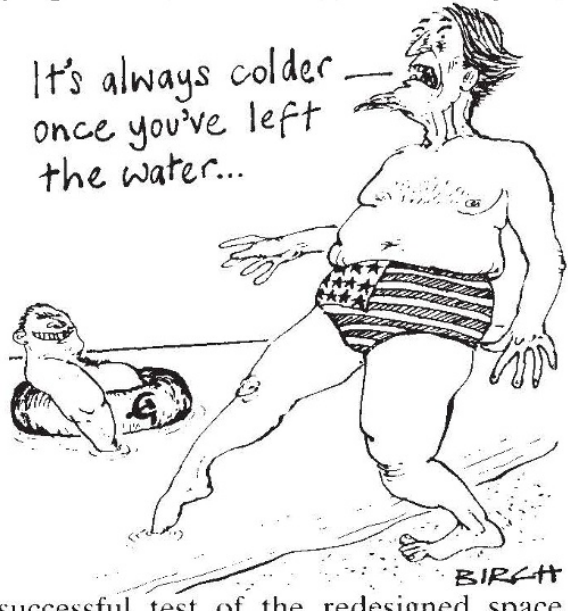
successful test of the redesigned space shuttle motors (Nature 329, 93; 1987), it does at least engender new confidence in the ability of the United States to put things into orbit. And the effort that has gone into the development of the Titan as a reliable launcher is a sign that both the civilian and military space programmes have recognized the danger of depending solely on the space shuttle.

The military payload sent into orbit on 26 October was not identified by the Air Force, but was reportedly a spy satellite of

Transfer of funds from the University Grants Committee to the research councils to pay for research overheads does not find much favour, with the AUT claiming that such a move would challenge the autonomy of the universities and would result in less effective targeting of funds.

Last week, the Secretary of State for Education, Mr Kenneth Baker, made clear his commitment to reform in the university system when he met vicechancellors.

Baker said that he did not believe the "old order" of higher education could have lasted. "Stumbling on in the old ways would in the long run do far more harm than radical change." He gave cause for tentative optimism, however, when he told the vice-chancellors that "the success of our policies is dependent on your cooperation."

The government's response to the ABRC document is expected early next year. It seems unlikely that any of the recommendations will be incorporated into the forthcoming education bill, whose publication is expected within the next few weeks.

Simon Hadlington

\title{
United States cheered by its successful Titan launch
}

the type designated $\mathrm{KH}-11$. The reconnaissance capabilities of the US Department of Defense have suffered enormously from the Titan and shuttle failures, and there is speculation that the launch, which was unannounced, succeeded in replacing the last active KH-11 only weeks before its anticipated 3-year lifetime expired.

In the civilian space programme, the next four scientific missions planned by the National Aeronautics and Space Administration (NASA), the Magellan, Galileo. Ulysses and Mars Observer projects, are all intended to use the shuttle. (NASA announced on 22 October a revised shuttle launch schedule, reducing the number of flights in the first year, but the slots for the planned science missions have been maintained.) The earliest use expected of a Titan rocket is not until the spring of 1993, for an as-yet unapproved comet rendezvous, although there is still a possibility that Mars Observer could be sent aloft on a Titan. For Geoffrey Briggs, NASA's director of Solar System exploration, the wider significance of last week's launch lies in the availability of the Titan as a back-up launch vehicle should the resumption of shuttle flights suffer further delays. Even before the Challenger disaster, there was criticism of NASA's reliance on a single launch vehicle, and although Briggs says that some problems still remain, NASA has learned its lesson and is actively seeking to maintain a varied launching fleet.
David Lindley 